\title{
Methodology for the design of a stand-alone photovoltaic power supply
}

\author{
Metodología para el diseño de un sistema fotovoltaico autónomo \\ de suministro de energía \\ Julio López Seguel ${ }^{1} \quad$ Seleme Isaac Seleme Junior ${ }^{2} \quad$ Pedro F. Donoso-Garcia ${ }^{2}$ \\ Lenin Martins Ferreira Morais ${ }^{2} \quad$ Porfírio Cabaleiro Cortizo ${ }^{2} \quad$ Marcos A. Severo Mendes $^{2}$ \\ Recibido 27 de marzo de 2012, aceptado 24 de abril de 2013 \\ Received: March 27, 2012 Accepted: April 24, 2013
}

\begin{abstract}
RESUMEN
Este trabajo presenta una completa metodología para el diseño de un sistema fotovoltaico autónomo que maximiza el uso de la energía solar. El método propuesto prioriza la mejor opción en términos de eficiencia en cada etapa del proyecto. Para asegurar el correcto funcionamiento y extender la vida útil de la batería se propone una estrategia de control para el proceso de carga. Resultados experimentales son proporcionados para un sistema fotovoltaico autónomo de baja potencia eléctrica destinado principalmente para la iluminación y electrodomésticos básicos de hogares de bajos ingresos.

Palabras clave: Sistemas de energía fotovoltaica, convertidores de potencia DC-DC, almacenamiento de energía, electrónica de potencia, buck.

ABSTRACT

This paper presents a complete methodology for the design of an autonomous photovoltaic system to maximize the use of solar energy. It is a method that prioritizes the best cost-effective choice at every step of the project. In order to ensure the proper use and extended battery life time, a control strategy for charging the batteries is proposed. Experimental results are provided for a stand-alone photovoltaic system with low electrical power, intended primarily for the illumination and basic appliances of lowincome households.
\end{abstract}

Keywords: Photovoltaic power systems, DC-DC power converters, energy storage, power electronics, buck.

\section{INTRODUCTION}

Autonomous photovoltaic systems are characterized by having only the energy generated by photovoltaic panels as their source. Thus, one needs an energy storage device, usually a battery bank, to ensure power supply at night or in periods of low solar incidence. In general a single photovoltaic power system is basically composed of an array of photovoltaic modules, a charge controller, one or more batteries and an inverter, in case there are loads operating with AC voltage.

A stand-alone photovoltaic system requires maximizing the use of solar energy and the energy storage in reserve, to achieve economic and technical sustainability. The low conversion efficiency of commercial solar modules between 6 and 16\% [1] and the high cost of installation are the major obstacles of this type of generation. In order to increase the

\footnotetext{
1 Facultad de Ingeniería y Arquitectura. Universidad Arturo Prat. Av. Arturo Prat No 2120. Iquique, Chile. E-mail: julio.lopez.seguel@unap.cl

2 Departamento de Engenharia Eletrônica. Universidade Federal de Minas Gerais. Av. Antônio Carlos Nº 6627. Belo Horizonte, Brasil. E-mail: seleme@cpdee.ufmg.br; pedro@cpdee.ufmg.br; lenin@cpdee.ufmg.br; porfirio@cpdee.ufmg.br
} 
efficiency of the system and, thus, reduce the cost of the energy generated, it is necessary to ensure that the system operates as long as possible on the point of maximum power of the panels. However, due to the characteristics of photovoltaic panels this point is variable and highly dependent on weather conditions and the system load. To ensure the operation of photovoltaic modules at the point of maximum power, even with weather variations and variations in load, the use of a technique that continuously seeks the point of maximum power must be used. These control algorithms are known as MPPT (maximum power point tracking) and can increase the energy produced between 15 and $30 \%$ [2].

One of the main factors for the successful use of a photovoltaic system isolated from the grid is the correct sizing of its components. The basic parameters to consider are: the amount of energy to be produced in terms of the amount of energy being consumed. The design should aim to obtain a compromise between the photovoltaic energy available and the expected energy demand. In order to maximize the autonomy of the system, we consider it necessary to use high efficiency illumination of the LED or fluorescent lights which use an electronic ballast to manage the energy consumed in lighting. These electronic ballasts can be fed through a DC bus. We also consider the need for AC voltage bus to the appliances which use this kind of voltage. Another important factor is the reliability of the system, which basically depends on the autonomy of the system face to prolonged periods without sunshine. Some similar studies have been published in the literature for different applications and context [3-4].

This paper presents a methodology for sizing of the main components of an autonomous photovoltaic system in series connection. In a series system (Figure 1), the battery bank is placed in series with the flow of energy. The battery charger has two purposes, first to ensure the added battery lifetime via an appropriate voltage control of the loading process, and second to ensure by means of some MPPT technique to maximize the capture of solar energy provided by the PV array. The MPPT acts on the duty cycle to achieve maximum power voltage (Vmax) of the panels. Furthermore, the voltage control uses as reference for the batteries the optimum battery charge voltage $(\mathrm{Vch})$ in order to regulate the duty cycle, since Vmax and Vch usually do not coincide. The MPPT and the voltage control must be independent, therefore, one needs a proper strategy to discern which of the controls will be in operation.

An example will be presented where the conditions of solar energy available in the region are defined, and the expected energy consumption of the residence and the autonomy of the system is provided. From the definitions above mentioned the sizing of the PV array, the battery bank and the battery charger is made. A strategy for the control of the power converter is also proposed. It should be noted that the sizing of the inverter is not addressed in this work.

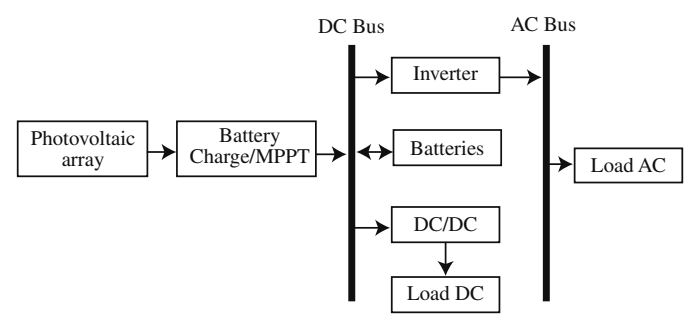

Figure 1. Block diagram of a stand-alone series photovoltaic power supply.

\section{SOLAR ENERGY CONSUMPTION EXPECTED AND AVAILABLE}

\section{Determination of energy consumption of the residence}

The expected daily power consumption was defined considering a stand-alone photovoltaic system with low electrical power, intended primarily for the illumination and basic appliances of low-income households. High efficiency lamps, low consumption domestic appliances and standard times of use provided by [5] were considered. Table 1 shows the installed load for residence under study, 98 (W), and the daily energy consumption (DEC), approximately 326 (Wh/day).

\section{Levels of solar radiation of the locality}

Belo Horizonte in Minas Gerais, Brazil was the location chosen for the installation of the system. Meteorological information was obtained through the database of solar potential from CEPEL (reference center for solar and wind power - Brazil) [6]. The average rates of solar radiation of Araxá, the closest city to Belo Horizonte where records are available, were considered. The database from CEPEL gives 
Table 1. Energy consumption expected in the household.

\begin{tabular}{|l|c|c|c|}
\hline \multicolumn{1}{|c|}{ Loads } & $\begin{array}{c}\text { Power } \\
\text { (W) }\end{array}$ & $\begin{array}{c}\text { Use } \\
\text { (h/day) }\end{array}$ & $\begin{array}{c}\text { Energy } \\
\text { (Wh/day) }\end{array}$ \\
\hline Livingroom lamp & 11 & 4 & 44 \\
\hline Bedroom 1 lamp & 8 & 3 & 24 \\
\hline Bedroom 2 lamp & 8 & 3 & 24 \\
\hline Bathroom lamp & 8 & 1 & 8 \\
\hline Kitchen lamp & 8 & 3 & 24 \\
\hline Satelite receptor & 10 & 4 & 40 \\
\hline Color TV 14" & 36 & 4 & 144 \\
\hline Stereo system & 9 & 2 & 18 \\
\hline Total & 98 & & 326 \\
\hline
\end{tabular}

the rate of solar radiation to the angle that provides the highest monthly minimum. Table 2 shows the values of radiation for the plane inclined at 13 degrees from the horizontal and pointed toward geographic north, which maximizes the average of the month. As the photovoltaic system must guarantee the energy supply during all months of the year, the lowest incidence rate, which corresponds to the month of June, with a daily rate of $4.90 \mathrm{kWh} / \mathrm{m}^{2}$, must be consider for the design.

Table 2. Monthly average daily radiation (kWh / $\mathrm{m}^{2}$ ) in Araxa for the installation angle of the modules which provides the highest monthly minimum $\left(13^{\circ}\right.$ to the geographic North)

\begin{tabular}{|l|c|}
\hline \multicolumn{1}{|c|}{ Month } & Radiation \\
\hline January & 5.10 \\
\hline February & 5.14 \\
\hline March & 5.30 \\
\hline April & 5.01 \\
\hline May & 5.08 \\
\hline June & 4.90 \\
\hline July & 5.41 \\
\hline August & 5.63 \\
\hline September & 5.10 \\
\hline October & 5.38 \\
\hline November & 5.11 \\
\hline December & 4.92 \\
\hline Average & 5.17 \\
\hline \multicolumn{2}{|c|}{} \\
\hline
\end{tabular}

\section{PV ARRAY AND BATTERY BANK}

\section{Sizing the PV array}

To make a correct sizing of the panels and other components of the system, it is important to know, besides the radiation conditions of the locality in which the system will be deployed, and the characteristics of the load, other parameters which are also important: the voltage levels that the system will operate are and, moreover, what the estimated losses of system components photovoltaic are.

Regarding the operating voltage of the system, it was fixed at 24 volts, to reduce the dc current, and consequently reduce the gauge of cables used in photovoltaic system installations. The fact of reducing the current flowing through the system has a positive impact on its efficiency, because the losses in the electronic components of the $\mathrm{dc} / \mathrm{dc}$ converter are significantly reduced [3]. Another benefit of using a voltage of 24 volts is the wide range of commercially available devices that work with this inverter input voltage.

As for the estimation of losses in the wiring, in the battery stack, in the dc/dc converter and in the inverter, default values suggested in [6] were used. These values are presented in Table 3. It is important to mention that to calculate the system losses, estimate losses for a commercial drive were also included. Even though it is not our objective to study the dc/ac conversion stage, it is necessary to consider it for the correct sizing of the system.

The calculation of the minimum capacity of generation of the photovoltaic modules is determined by the solar energy accumulated (SEA) during the day in the location where the system will be installed. A convenient parameter to express the cumulative value of this energy is the number of hours of full sun, i.e., the number of hours that the solar radiation must remain constant and equal to $1 \mathrm{~kW} / \mathrm{m}^{2}$ incident light power in "standard test condition" (STC), as defined by IEC 61215 [7].

Table 3. Parameters for sizing the PV system.

\begin{tabular}{|l|c|}
\hline Installed load & $98 \mathrm{~W}$ \\
\hline Daily energy consumption $(\mathrm{DEC})$ & $326 \mathrm{Wh} /$ day \\
\hline Monthly average daily radiation & $4.9 \mathrm{w} / \mathrm{m}^{2}$ \\
\hline Operating voltage of the DC $\left(\mathrm{V}_{\mathrm{DC}}\right)$ & $24 \mathrm{~V}$ \\
\hline AC output voltage $\left(\mathrm{V}_{\mathrm{AC}}\right)$ & $110 \mathrm{~V}$ \\
\hline Wiring efficiency* $\left(\eta_{\mathrm{w}}\right)$ & $98 \%$ \\
\hline Battery bank efficiency* $\left(\eta_{\text {batt }}\right)$ & $95 \%$ \\
\hline Inverter efficiency* $\left(\eta_{\text {inv }}\right)$ & $85 \%$ \\
\hline DC converter efficiency* $\left(\eta_{\mathrm{DC}}\right)$ & $90 \%$ \\
\hline
\end{tabular}

* Default value suggested in [6]. 
For the city of Belo Horizonte, the number of hours of full sun (FS) is:

$$
\mathrm{FS}=\frac{\mathrm{SEA}}{\mathrm{STC}}=\frac{4.9 \mathrm{kWh} / \mathrm{m}^{2}}{1 \mathrm{~kW} / \mathrm{m}^{2}}=4.9 \mathrm{~h}
$$

One can say that the value of $4.9 \mathrm{kWh} / \mathrm{m}^{2}$ of daily radiation is produced by 4.9 hours of constant incident power at $1000 \mathrm{~W} / \mathrm{m}^{2}$. Thus, the parameters adopted for calculating the array of photovoltaic panels and other system components are presented in Table 3.

The specifications of the necessary minimum power $\left(\mathrm{P}_{\min }\right)$ from the $\mathrm{PV}$ generator must be:

$$
\mathrm{P}_{\min }=\frac{\mathrm{DEC}}{\mathrm{FS}}=\frac{326 \mathrm{Wh}}{4.9 \mathrm{~h}}=66.53 \mathrm{~W}
$$

Considering the efficiency of the components $\left(\eta_{T}\right)$, the minimum power must be corrected $\left(\mathrm{P}_{\min \text { Corr }}\right)$ using equation (3):

$\mathrm{P}_{\text {minCorr }}=\frac{\mathrm{P}_{\min }}{\eta_{\mathrm{T}}}=\frac{66.53 \mathrm{~W}}{(0.98 \cdot 0.95 \cdot 0.85 \cdot 0.9)}=93.41 \mathrm{~W}$

where: $\eta_{\mathrm{T}}=\eta_{\mathrm{W}} \cdot \eta_{\text {batt }} \cdot \eta_{\text {inv }} \cdot \eta_{\mathrm{DC}}$

Because weather conditions vary, it is necessary to store enough energy not only for a night time, but for longer intervals with below-average solar radiation. It was determined that the system should have an autonomy of 2 days (according to regulatory resolution $\mathrm{N}^{\circ}$ 83, September 20, 2004 ANEEL [8], the Brazilian Agency for Electric Energy, which determines this minimum value for low consumption systems) and that, upon returning from a condition of maximum discharge, it fully recharges in 3 days of normal sunlight (FRD).

The calculation of the power to maintain the autonomy of the system $\left(\mathrm{P}_{\text {aut }}\right)$, i.e., the power that the battery bank must supply to the loads can be calculated by equation (4). Therefore, the minimum power for 2 cloudy days shall be:

$\mathrm{P}_{\text {aut }}=\mathrm{P}_{\text {minCorr }}\left(1+\frac{\mathrm{NCD}}{\mathrm{FRD}}\right)=93.41 \cdot\left(1+\frac{2}{3}\right)=155.68 \mathrm{~W}$

where NCD corresponds to the number of cloudy days.
For the case studied, two photovoltaic panels of $80 \mathrm{~W}$ nominal power were chosen, connected in series to provide a nominal voltage of 24 volts, thus a nominal installed power of $160 \mathrm{~W}$. Two Isofoton panels model I-80 NP were used.

\section{Sizing of the battery bank}

For the sizing of the battery stack two important parameters should also be considered: the autonomy of the system and the depth of discharge for batteries accepted. The autonomy of the system corresponds to the number of days in which the energy stored in the battery stack is sufficient to meet demand without any spare energy by the photovoltaic panels. This parameter representing the reliability of the PV; however the increase in the number of days of autonomy of the system leads to a direct increase in the cost of the battery stack and consequently the cost of the system.

The depth of discharge of a battery is directly related to its lifetime. As can it be seen in Figure 2, the use of a high depth of discharge impacts significantly the battery lifetime.

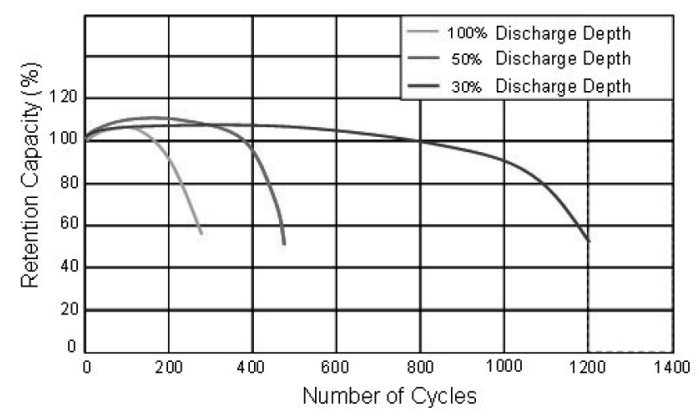

Figure 2. Charge retention capacity with chargedischarge cycles for three maximum depths of discharge in lead acid batteries [9].

The daily energy consumption of the PV system, considering the losses, is:

$\mathrm{E}=\frac{\mathrm{DEC}}{\eta_{\mathrm{T}}}=\frac{326 \mathrm{Wh}}{(0.98 \cdot 0.95 \cdot 0.85 \cdot 0.9)}=457.72 \mathrm{Wh}$

The capacity (C) of the battery bank can be calculated from the total energy to be stored (equivalent to three days of operation - NDO) and the nominal voltage $\left(\mathrm{V}_{\mathrm{DC}}\right)$ : 


$$
\mathrm{C}=\frac{\mathrm{NDO} \cdot \mathrm{E}}{\mathrm{V}_{\mathrm{DC}}}=\frac{3 \cdot 457.72 \mathrm{Wh}}{24 \mathrm{~V}}=57.21 \mathrm{Ah}
$$

The capacity value calculated in (6) implies that on average the batteries will be subjected to daily cycles with depth of discharge at around $33 \%$. In order to guarantee a minimum period of operation of the storage system of three years, one can determine that $57.21 \mathrm{Ah}$ is equivalent to $80 \%$ of total capacity. It can also be observed from Figure 2 that, for a depth of discharge $30 \%$, the number of guaranteed cycles is approximately 1100 . Thus, the minimum capacity of the batteries $\left(\mathrm{C}_{\text {corr }}\right)$ is:

$$
\mathrm{C}_{\text {corr }}=\frac{\mathrm{C}}{0.8}=\frac{57.21 \mathrm{Ah}}{0.8}=71.51 \mathrm{Ah}
$$

Two batteries were chosen: brand Newmax FNC, model 12800,80 Ah capacity and nominal voltage of 12 volts each. The batteries are connected in series in order to provide the required voltage of 24 volts DC bus.

\section{Photovoltaic panel models}

In order to obtain a straightforward way of describing the electronic behavior of a photovoltaic cell it is useful to create an equivalent electric model. The simplest equivalent circuit of an ideal cell is that of a current source in parallel with a diode, having a series resistance, $\mathrm{R}_{\mathrm{S}}$ which describes the voltage drop, the losses of the semiconductor material, the metallic contacts and their junctions. Another resistance in parallel $R_{P}$ describes the losses of the electrical perturbations and perturbations in the $\mathrm{PN}$ transition zones. Figure 3 shows the photovoltaic model where $\mathrm{I}_{\mathrm{PH}}$ represents the generated current for a given radiation, the diode $\mathrm{D}$ represents the $\mathrm{PN}$ junction, I, is the current produced by the cell to the external circuit, $\mathrm{V}$ is the voltage at the output

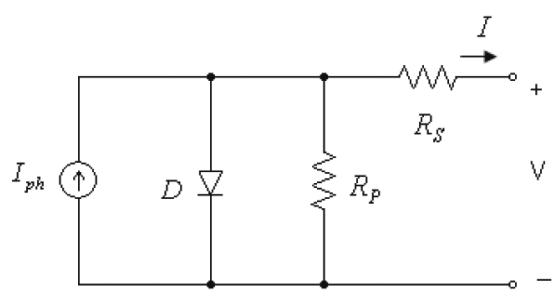

Figure 3. Photovoltaic Panel Model. terminals and $\mathrm{R}_{\mathrm{P}}$ and $\mathrm{R}_{\mathrm{S}}$ are the equivalent parallel and series resistances [10].

The Isofoton I-80 NP photovoltaic panel modeled based on the curves given by the manufacturer. The mathematical equations describing the panel are:

$$
\begin{gathered}
I=I_{p h}-I_{r} \cdot\left[e^{\frac{q \cdot\left(V+I \cdot R_{S}\right)}{n \cdot k \cdot T}}-1\right]-\frac{V+I \cdot R_{S}}{R_{P}} \\
I_{r}=I_{r r} \cdot\left(\frac{T}{T_{r}}\right)^{3} \cdot e^{\left[\frac{q \cdot E_{G}}{n \cdot k} \cdot\left(\frac{1}{T_{r}}+\frac{-1}{T}\right)\right]} \\
I_{p h}=\left[I_{S C}+\alpha \cdot\left(T-T_{r}\right)\right] \cdot \frac{P_{s u n}}{1000}
\end{gathered}
$$

with the parameters in Table 4, where $V$ is the output voltage, I the output current, $\mathrm{I}_{\mathrm{ph}}$ the photocurrent, $\mathrm{I}_{\mathrm{r}}$ the reverse saturation current, $\mathrm{n}$ ideality factor of the junction, $\mathrm{T}$ the environment temperature, $\mathrm{q}$ the electron charge, $\mathrm{k}$ the Boltzmann constant, $\mathrm{I}_{\mathrm{SC}}$ the short circuit current, $\alpha$ the short circuit temperature coefficient of the cell, $T_{\mathrm{r}}$ the reference temperature, $\mathrm{P}_{\text {sun }}$ the incident radiation, $\mathrm{I}_{\mathrm{rr}}$ the reverse saturation current at $T_{r}$ and $E_{G}$ the silicon band-gap energy.

Table 4. Parameters for the I-80 NP photovoltaic panel.

\begin{tabular}{|c|c|}
\hline Parameter & Value \\
\hline $\mathrm{I}_{\mathrm{SC}}$ & $6.3 \mathrm{~A}$ \\
\hline $\mathrm{V}_{\mathrm{OC}}$ & $21.6 \mathrm{~V}$ \\
\hline $\mathrm{T}_{\mathrm{r}}$ & $298.15 \mathrm{~K}$ \\
\hline $\mathrm{I}_{\mathrm{rr}}$ & $1.7787 \mathrm{e}-8 \mathrm{~A}$ \\
\hline$\alpha$ & $1.18 \mathrm{~mA} / \mathrm{K}$ \\
\hline$n$ & 1.2 \\
\hline $\mathrm{R}_{\mathrm{P}}$ & $0.46 \Omega$ \\
\hline $\mathrm{R}_{\mathrm{S}}$ & $7 \mathrm{~m} \Omega$ \\
\hline $\mathrm{E}_{\mathrm{G}}$ & $1.1 \mathrm{eV}$ \\
\hline$k$ & $1.38 \mathrm{e}-23 \mathrm{~J} / \mathrm{K}$ \\
\hline $\mathrm{q}$ & $1.6 \mathrm{e}-19 \mathrm{C}$ \\
\hline
\end{tabular}

The obtained model matches very well the curves given by the manufacturer, as can be seen in Figure 4. Details on the procedure of model fitting are presented in [11] where the authors describe a procedure to fit the model behavior to that obtained with commercial modules. 


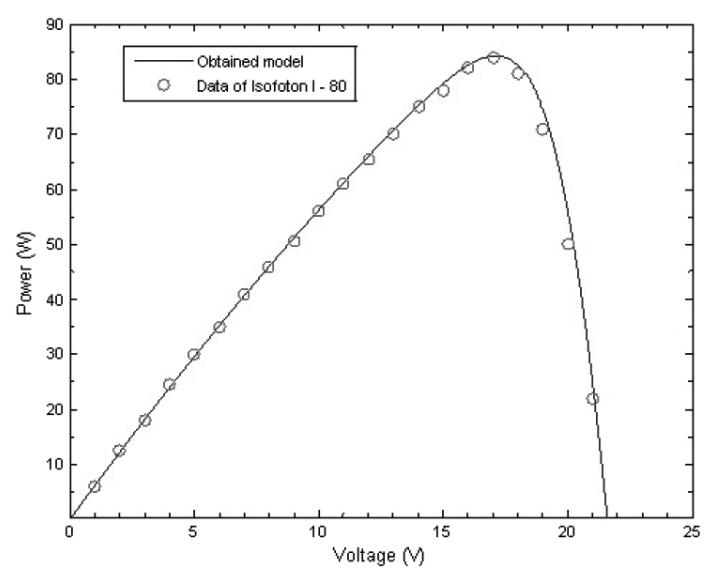

Figure 4. Matching between the model and the manufacturer curve with radiation Psun $=1000 \mathrm{~W} / \mathrm{m}^{2}$ and temperature $\mathrm{T}=25^{\circ} \mathrm{C}$.

\section{POWER CONVERTER}

\section{Choice of converter topology DC-DC}

Given the configuration of the PV array (two panels I Isofoton NP-80 connected in series), and the range of the operation voltage of the battery stack (between 21-28.8V), the topologies best suited for the battery charger would be the Buck topology and Buck-Boost topology (acting only as a voltage step-down), since the maximum power voltage of the PV array is the larger than the operating voltage over a wide range of incident radiation (Figure 5).

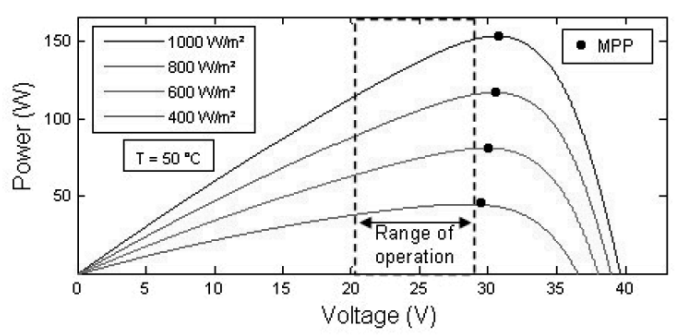

Figure 5. Operating range of the charge controller obtained from the simulation of the PV array.

From the standpoint of ease of implementation, the Buck converter would be more appropriate, since the Buck-Boost converter inverts output voltage, which could lead to a more complex wiring diagram to analyze and implement [11]. Nevertheless it is not a conclusive argument. Thus, given the application for which the converters are designed, it is assumed that an analysis on the relation of powers $\left(\mathrm{P}_{\mathrm{O}} /\right.$ $\mathrm{P}_{\mathrm{T}}$ ) is the most appropriate. In this analysis, $\mathrm{P}_{\mathrm{O}}$ represents the power output of the converter and $\mathrm{P}_{\mathrm{T}}$ the power used by the switching elements. For the analysis described one assumes that: a) the current ripple is neglected, i.e., the converter operates only in continuous conduction mode, b) the output voltage ripple is negligible. c) the input voltage can vary, implying that the duty cycle must be controlled to maintain constant output voltage. With these assumptions, it is possible to calculate the peak voltage and current in the switch, allowing the calculation of $\mathrm{P}_{\mathrm{T}}$. By knowing this value it is possible to draw the curves that relate the switch loss power with the output power for the cycle. These curves are shown in Figure 6 for various DC/DC converters [10].

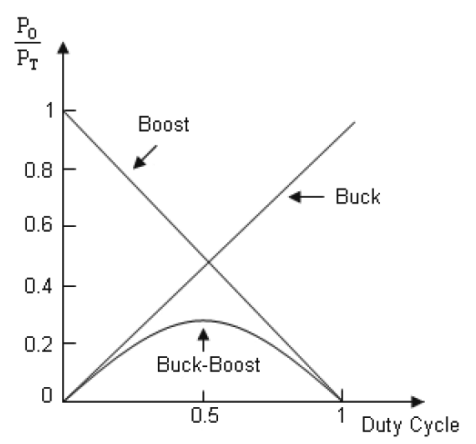

Figure 6. Energy use in several DC/DC converters.

It can be seen from Figure 6 that the use of the switching elements in Buck converters is quite good, since the output voltage and input are of the same order of magnitude. Rather, the Buck-Boost converter switches have a lower rate of use from the point of view of energy efficiency, peaking at $25 \%$ with a duty cycle of 0.5 , i.e., for situations where the input voltage is equal to the output. Thus, since energy efficiency is very important for photovoltaic applications, the choice of a Buck converter is considered, for the case studied, the most appropriate. Figure 7 shows the typical topology of a Buck converter.

\section{Selection of the inductor}

A Buck converter operating in continuous conduction mode presents the following relationship between the average input voltage $\mathrm{V}_{\mathrm{i}}$, and output voltage, $V_{o}$ in steady state: $V_{0}=D V_{i}$. When considering the boundary condition of maximum power available, an 


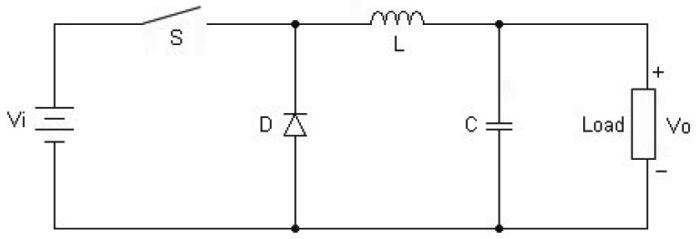

Figure 7. Buck converter topology.

incident radiation of $1000 \mathrm{~W} / \mathrm{m}^{2}$ and the temperature of the modules as equal to $15^{\circ} \mathrm{C}$, one can obtain by simulation, the operation of the arrangement. As it can be seen form Figure 8, the open circuit voltage $\mathrm{V}_{\mathrm{oc}}=44.6 \mathrm{~V}$, the maximum power voltage $\mathrm{V}_{\max }=$ $35.74 \mathrm{~V}$, the maximum power current, $\mathrm{I}_{\max }=4.88$ $\mathrm{A}$, and the maximum power being $\mathrm{P}_{\max }=174.57 \mathrm{~W}$.
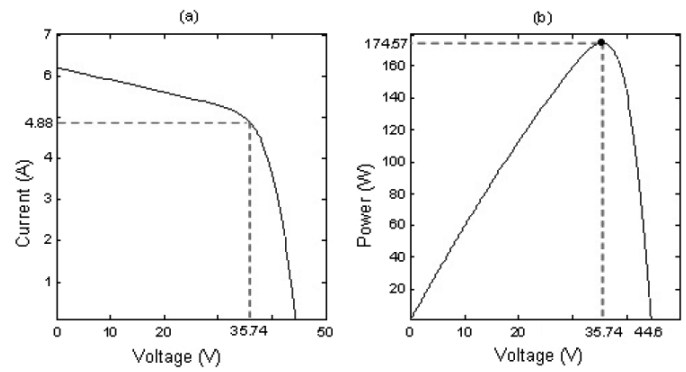

Figure 8. Simulation curves for the PV array given as a radiation boundary condition of 1000 $\mathrm{W} / \mathrm{m}^{2}$ and panel temperature of $15^{\circ} \mathrm{C}$.

Since the module power depends on the voltage at its terminals and consequently on the duty cycle, and that in the ideal power converter, input and output powers are equal, the output current should follow the power variation. The maximum average current, $\mathrm{I}_{0 \mathrm{max}}$, in the output occurs for the maximum power condition of PV array (174.57 W) and a minimum voltage at the battery stack $(21 \mathrm{~V})$. So, the maximum average current, $\mathrm{I}_{0 \max }=174.57 \mathrm{~W} / 21 \mathrm{~V}=8.31 \mathrm{~A}$.

Considering an ideal Buck and neglecting the output voltage ripple, the inductor current ripple in output can be given by the following relationship [11]:

$$
\Delta \mathrm{i}_{\mathrm{L}}=\frac{\mathrm{V}_{\mathrm{i}} \cdot \mathrm{D}(1-\mathrm{D})}{\mathrm{f} \cdot \mathrm{L}}
$$

Where $\mathrm{f}$ is the switching frequency and $\mathrm{L}$ is the inductance of the output filter, D is the duty cycle of the converter and Vo is the average voltage output. Thus, for a given $\mathrm{V}_{\mathrm{o}}$, the maximum ripple occurs when $\mathrm{D}$ is minimum and the converter input voltage is maximum. However, the minimum value of $\mathrm{D}$ depends on $\mathrm{V}_{\mathrm{o}}$ according to:

$$
\mathrm{D}_{\min }=\frac{\mathrm{V}_{0}}{\mathrm{~V}_{\text {imax }}}
$$

So the maximum current ripple in the inductor for a given operating condition can be represented as:

$$
\Delta \mathrm{i}_{\mathrm{L} \max }=\frac{\mathrm{V}_{\mathrm{imax}} \cdot \mathrm{D}_{\min }\left(1-\mathrm{D}_{\min }\right)}{\mathrm{f} \cdot \mathrm{L}}
$$

From equation (13) it is clear that the maximum ripple current in the inductor is when $D_{\min }\left(1-D_{\min }\right)$ is maximum. Figure 9 shows the curve of $D_{\min }(1-$ $\left.\mathrm{D}_{\text {min }}\right)$ as a function of the battery bank voltage. Here we see that for a voltage of $22.3 \mathrm{~V}$ in the battery bank (duty cycle $\mathrm{D}=0.5$, considering $\mathrm{V}=44.6$ ) one has the highest value for $D_{\min }\left(1-D_{\min }\right)=0.25$ and as a result the highest inductor current ripple. Defining a switching frequency of $24 \mathrm{kHz}$ for the project, and accepting a current ripple of $10 \%$ of the maximum average output current $\mathrm{I}_{0 \max }$, one obtains the value of the inductance for the inductor from equation (13).

$$
\mathrm{L}=\frac{44.5 \cdot 0.25}{24000 \cdot 0.1 \cdot 8.31}=558 \mu \mathrm{H}
$$

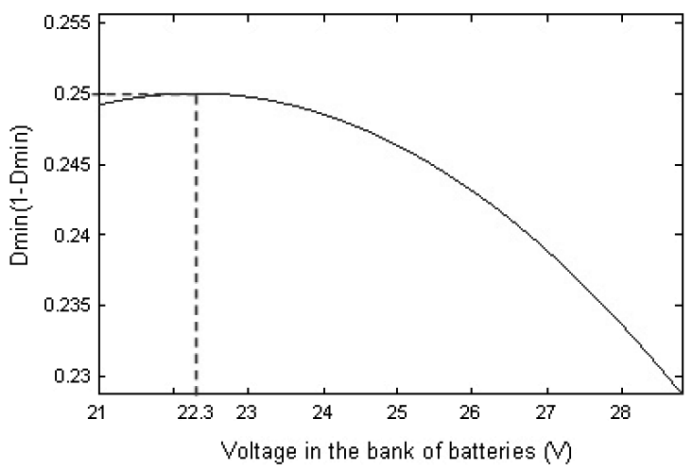

Figure 9. Simulation curve $\mathrm{D}_{\min }\left(1-\mathrm{D}_{\min }\right)$ as a function of the voltage at the battery bank for $\mathrm{V}_{\text {imax }}=44.6 \mathrm{~V}$.

\section{Selection of the output capacitor}

The alternating component of the inductor current circulates in the output capacitor $\mathrm{C}$ of Buck converter, while the dc component circulates in the battery 
bank. The current in the capacitor causes both a variation of the charge in the capacitor as well as a voltage drop across the parasitic series resistance. Below are given the expressions of the capacitor voltage ripple caused by the load variation $\left(\Delta \mathrm{V}_{0 \text {,cap }}\right)$ (14) and the voltage ripple $\left(\Delta \mathrm{V}_{0, \mathrm{RSE}}\right)$ caused by the equivalent series resistance (RSE), respectively (15) [11]:

$$
\begin{gathered}
\Delta \mathrm{V}_{0, \text { cap }}=\frac{\Delta \mathrm{i}_{\mathrm{L}}}{8 \cdot \mathrm{C} \cdot \mathrm{f}} \\
\Delta \mathrm{V}_{0, \mathrm{RSE}}=\Delta \mathrm{i}_{\mathrm{L}} \cdot \mathrm{RSE}
\end{gathered}
$$

A maximum ripple voltage caused by load variation of $1 \%$ of the minimum value of the average output voltage is acceptable. Thus, by manipulating equation (14), one determines the minimum capacitance of the output capacitor:

$$
\mathrm{C}=\frac{\Delta \mathrm{i}_{\mathrm{L}}}{\Delta \mathrm{V}_{\mathrm{O}, \text { cap }} \cdot 8 \cdot \mathrm{f}}=\frac{0.1 \cdot 8.31}{0.01 \cdot 21 \cdot 8 \cdot 24000}=19.85 \mu \mathrm{F}
$$

For the voltage ripple caused by the parasitic series resistance, one chooses also a maximum value of $1 \%$ of the minimum value of the average output voltage. Thus with (15) one calculates the maximum parasitic resistance admissible for selecting the capacitor:

$$
\mathrm{RSE}=\frac{\Delta \mathrm{V}_{0, \mathrm{RSE}}}{\Delta \mathrm{i}_{\mathrm{L}}}=\frac{0.01 \cdot 21}{0.1 \cdot 8.31}=252.7 \mathrm{~m} \Omega
$$

\section{Selection of the Mosfet}

For the choice of Mosfet, its losses were calculated. These losses, when a Mosfet is used in a static converter, are analogous to the losses of a bipolar transistor, i.e., a portion is associated with the conduction losses and the other with the switching losses. The total losses in the Mosfet as a function of the duty cycle can be estimated as [12]:

$$
\mathrm{P}_{\text {mosfet }}=\mathrm{r}_{\mathrm{ds}} \mathrm{I}_{\mathrm{o}}^{2} \mathrm{D}+\frac{\mathrm{v}_{\mathrm{i}} \mathrm{I}_{0} \mathrm{f}}{6}\left(\mathrm{t}_{\mathrm{r}}+\mathrm{t}_{\mathrm{f}}\right)+\frac{\mathrm{f}}{2} \mathrm{C}_{\mathrm{ds}} \mathrm{V}_{\mathrm{i}}^{2}
$$

In which $\mathrm{r}_{\mathrm{ds}(\text { on) }}$ corresponds to the drain-source resistance when conducting, $\mathrm{I}_{0}$ is the average switch current, $\mathrm{D}$ is the duty cycle, $\mathrm{V}_{\mathrm{i}}$ is the drain-source voltage applied to the Mosfet, $\mathrm{f}$ the switching frequency, $t_{r}$ the rise time of current and $t_{f}$ is the fall time of the current in Mosfet, while $\mathrm{C}_{\mathrm{ds}}$ is its drain-source capacitance.

After testing several models, the one with the smallest losses, the IRF540Z International Rectifier Mosfet was chosen. Table 5 presents the most relevant parameters required for this Mosfet loss calculation. Figure 10 shows the simulation of the total losses as a function of the duty cycle for the Mosfet chosen. The highest loss occurs for a duty cycle $\mathrm{D}=0.605$ and corresponds to $1.407 \mathrm{~W}$.

Table 5. Electrical characteristics of Mosfet IRF540Z.

\begin{tabular}{|c|c|}
\hline Parameter & Value \\
\hline $\mathrm{V}_{\mathrm{DSS}}$ & $100 \mathrm{Vdc}$ \\
\hline $\mathrm{r}_{\mathrm{ds}(\mathrm{on})}$ & $26.5 \mathrm{~m} \Omega$ \\
\hline $\mathrm{t}_{\mathrm{r}}$ & $51 \mathrm{~ns}$ \\
\hline $\mathrm{I}_{\mathrm{D}(\max )}$ & $36 \mathrm{~A} \mathrm{dc}$ \\
\hline $\mathrm{t}_{\mathrm{f}}$ & $39 \mathrm{~ns}$ \\
\hline $\mathrm{C}_{\mathrm{ds}}$ & $80 \mathrm{pF}$ \\
\hline
\end{tabular}

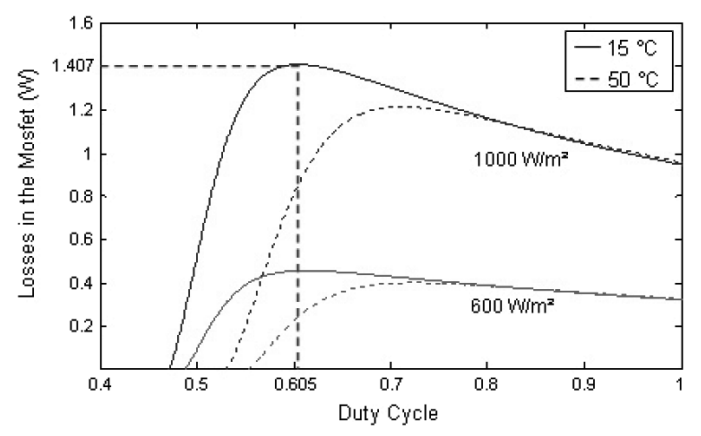

Figure 10. Simulation of the total losses in the Mosfet chosen as function of the duty cycle $\mathrm{D}$, for $\mathrm{V}_{\mathrm{o}}=21 \mathrm{~V}$.

\section{Selection of the Diode}

Just as in the case of the Mosfet, the diode presents conduction and switching losses. Because of using a Schottky diode in this project, the switching losses were ignored. Therefore, only the conduction losses were considered, which are given as a function of duty cycle for the Buck converter, as [10]:

$$
\mathrm{P}_{\text {diode }}=\left(\mathrm{V}_{\mathrm{f}} \cdot \mathrm{I}_{0}+\mathrm{r}_{\mathrm{T}} \cdot \mathrm{I}_{\mathrm{rms}}^{2}\right)(1-\mathrm{D})
$$

In which $r_{T}$ is the direct conduction resistance of the diode, $\mathrm{I}_{0}$ the average current through the diode, $\mathrm{I}_{\mathrm{rms}}$ the effective current through the diode, $\mathrm{D}$ the duty cycle and $V_{f}$ the voltage drop on the diode in 
conduction. The maximum average current that the diode must withstand is $8.31 \mathrm{~A}$, which is the condition of maximum power delivered by the PV array used in the design of the Buck converter. The maximum blocking voltage of the diode will be 44.6 $\mathrm{V}$, which is the open circuit voltage of the set for this weather. Another important parameter in the choice of the diode is related to losses: it is important that the diode has a low conductance resistance. After reviewing several models, we have chosen the MBR20100CT of International Rectifier, because it complies with project specifications and it was the one with the lowest losses of the diodes tested.

Table 6 presents the most relevant electrical parameters for the chosen diode, from its datasheet. Figure 11 shows the simulation for the calculation of losses for the Schottky diode as a function of duty cycle, D. The highest loss occurs for a duty cycle $\mathrm{D}=0.558$ and corresponds to $3.866 \mathrm{~W}$.

Table 6. Electrical characteristics of the diode MBR20100CT.

\begin{tabular}{|c|c|}
\hline Parameter & Value \\
\hline $\mathrm{I}_{\mathrm{F}(\mathrm{AV})}$ & $20 \mathrm{~A}$ \\
\hline $\mathrm{V}_{\mathrm{R}}$ & $100 \mathrm{~A}$ \\
\hline $\mathrm{V}_{\mathrm{f}}$ & $0.95 \mathrm{~V}$ \\
\hline $\mathrm{f}_{\mathrm{T}}$ & $15.8 \mathrm{~mW}$ \\
\hline
\end{tabular}

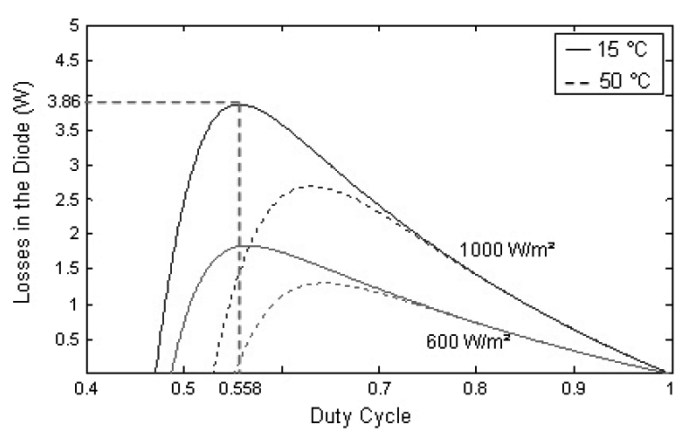

Figure 11. Simulation of the total losses in the diode Schottky as a function of duty cycle D, for $\mathrm{V}_{\mathrm{o}}=21 \mathrm{~V}$.

\section{CHARGER CONTROL STRATEGY}

The lead-acid batteries need a strategy to control their processes of loading and unloading to prevent early degradation of its active material and consequent reduction of its estimated lifetime. Thus, during the charging process the charger should match the flow of energy delivered from the battery to ensure a full charge within the limits of voltage, current and battery temperature. Also, during the process of discharging the driver should avoid the battery of discharging beyond its limit of energy supply.

A fast, safe and complete charging cycle of a Leadacid battery, according to some manufacturers, is to divide the process into three regions, which are: (1) charging the battery when deeply discharged (bulk charge); (2) overcharge region, which is an intermediate region and (3) float charge, when the battery is practically charged. Figure 12 describes the voltage-current characteristics of these three stages.

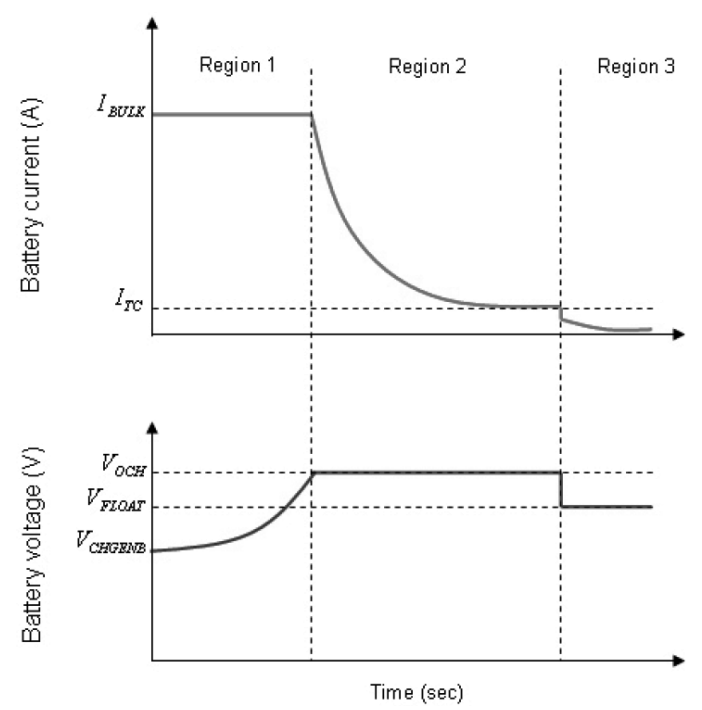

Figure 12. Battery charging region.

In order to provide a complete charge for the battery an elaborated control strategy must be applied, such that the battery would be charged as fast as possible, within its operation limits, given that the daily generation period for the photovoltaic panels is limited.

In the first region, corresponding to fully discharged battery it is important that the arrangement of photovoltaic modules operate at the maximum power to apply the largest admissible current to the batteries in order to charge them in the shortest time interval possible. That is when the MPPT technique is used. The algorithm implemented was the Incremental Conductance MPPT [13]. 
For the second region, corresponding to partially charged battery, it has been proposed a strategy of constant charging voltage with current limit. According to the manufacturers of batteries, this method is most suitable for lead-acid batteries, since it protects the battery against overload during the final stage of load fluctuation [14]. The strategy of constant voltage with current limit was implemented with two cascaded control loops, an inner loop to limit the recharging current and an outer loop to maintain constant reference voltage. This outer loop is regulated at the equalization voltage, i.e., $28.8 \mathrm{~V}$ [14].

For the third region, which is when the battery is almost fully charged, the same strategy as for the second region remains, only with a different voltage reference of $27 \mathrm{~V}$. To avoid a deep discharge, beyond what is admitted by the manufacturer, the controller will have to perform the disconnection of the load every time the voltage at the bank terminals reaches its minimum allowed value of $21 \mathrm{~V}$.

\section{Voltage control}

Figure 13 shows the proposed strategy for the control voltage, where $G_{V}(s)$ corresponds to the transfer function of the compensator loop voltage, $\mathrm{G}_{\mathrm{I}}(\mathrm{s})$ to the transfer function of the compensator current loop, $\mathrm{H}_{\mathrm{I}}(\mathrm{s})$ to the transfer function of the current sensor, $\mathrm{H}_{\mathrm{V}}(\mathrm{s})$ to the transfer function of the voltage sensor and $\mathrm{K}_{\mathrm{M}}(\mathrm{s})$ corresponds to the transfer function of the PWM modulator. For the linear model of the buck converter, $\mathrm{G}_{\mathrm{id}}(\mathrm{s})$ corresponds to the transfer function relating the work cycle $\hat{d}$ with the inductor current $\hat{i}_{L}, \mathrm{G}_{\mathrm{oi}}(\mathrm{s})$ corresponds to the transfer function relating $\hat{i}_{L}$ with the output voltage ${ }^{v_{o}}$. Blocks $\mathrm{G}_{\mathrm{iPV}}(\mathrm{s})$ and $\mathrm{G}_{\mathrm{ip}}(\mathrm{s})$ represent the

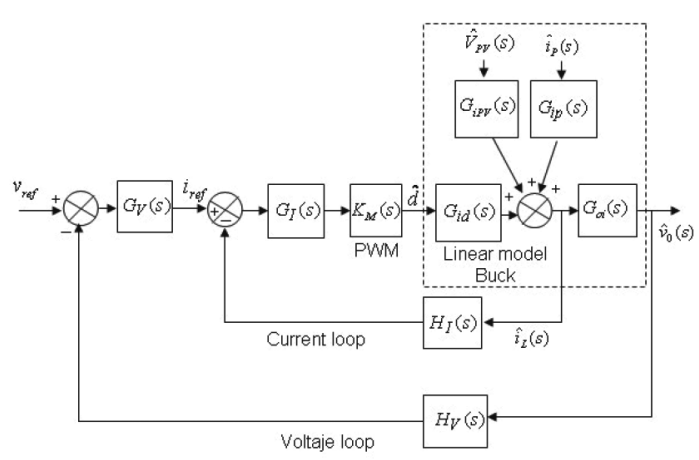

Figure 13. Block diagram of the voltage control. perturbations of small signal input voltage $\hat{\mathrm{V}}_{\mathrm{PV}}$ and load current $\hat{i}_{P}$ respectively, over $\hat{i}_{L}$.

\section{Modeling the Buck}

The transfer functions of the Buck linear model were obtained averaging the variables in state space which is valid for small variations around the point of operation at steady state. Detail of the approach is shown in [12]. The transfer functions obtained are shown below:

$G_{i P V}(s)=\frac{\hat{i}_{L}(s)}{\hat{V}_{P V}(s)}=\frac{0.0009544 \cdot s+0.8294}{6.443 \times 10^{-7} \cdot s^{2}+0.000859 \cdot s+5.04}(18)$

$G_{i d}(s)=\frac{\hat{i}_{L}(s)}{\hat{d}(s)}=\frac{0.04027 \cdot s+35}{6.443 \times 10^{-7} \cdot s^{2}+0.000859 \cdot s+5.04}$

$G_{i p}(s)=\frac{\hat{i}_{L}(s)}{\hat{i}_{P}(s)}=\frac{-0.000253 \cdot s-5}{6.443 \times 10^{-7} \cdot s^{2}+0.000859 \cdot s+5.04}$

$G_{0 i}(s)=\frac{\hat{v}_{0}(s)}{\hat{i}_{L}(s)}=\frac{0.000253 \cdot s+5}{0.001151 \cdot s+1}$

Aiming to prove the validity of the average model obtained for the Buck, its behavior was compared with the switched circuit, using the Power Systems toolbox of Matlab. Figure 14 shows the dynamics of the output voltage of the converter in response to a voltage step of $10 \%$ of provided voltage by the PV array. The result shows that the average model behaves satisfactorily. Several tests were made showing that for every small variation in the inputs of the converter resulted in accurate average voltage dynamics.

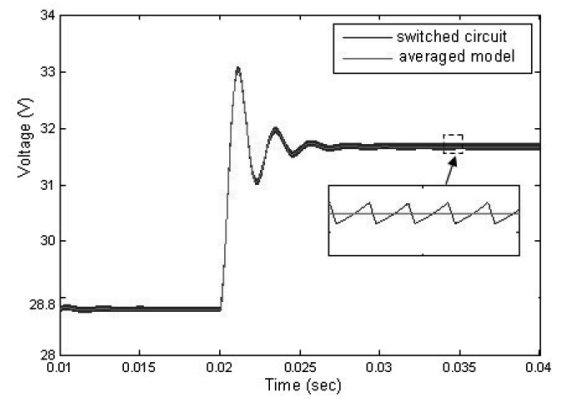

Figure 14. Comparison of the switched circuit and the average model behavior.

\section{Analogical compensators}

In order to obtain the digital compensators the indirect method was chosen. In other words, from the development of an analogical controller one obtains 
a discrete controller with similar performance for any given discretization technique. In this study we opted for the methodology proposed in [15] for the development of analogical compensators, the starting point being the frequency response of the converter, modeled with the average value of the variables.

Figure 15 shows the structure of the controllers used for both the loop voltage as for the current loop, which according to the methodology proposed in [15] has been suggested when the phase lead required is less than $90^{\circ}$. Its transfer function is shown in (22):

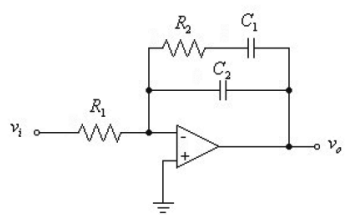

Figure 15. Structure of compensator used.

$$
\frac{v_{o}(s)}{v_{i}(s)}=\frac{1+s C_{1} R_{2}}{s R_{1}\left(C_{1}+C_{2}+s R_{2} C_{1} C_{2}\right)}
$$

The current controller was adjusted to have a phase margin of $60^{\circ}$ and a cutoff frequency of $1 / 5$ of the switching frequency, which is $4800 \mathrm{~Hz}$. Equation (23) shows the transfer function obtained. The voltage controller was set to have a phase margin of $60^{\circ}$ and a cutoff frequency of $1 / 25$ of the switching frequency, which is $960 \mathrm{~Hz}$. Equation (24) shows that the transfer function designed for this controller.

$$
\begin{aligned}
G_{I}(s) & =\frac{1+0.00012 \cdot s}{2.297 \cdot 10^{-11} \cdot s^{2}+2.506 \cdot 10^{-6} \cdot s} \\
G_{V}(s) & =\frac{1+0.0003448 \cdot s}{2.205 \cdot 10^{-8} \cdot s^{2}+0.0002766 \cdot s}
\end{aligned}
$$

Figure 16 shows the Bode plots for the designed current compensator, for the system without compensation and for the compensated system. The analysis of the diagram shows that all established specifications are met: cutoff frequency of 4.8 $\mathrm{kHz}$ and phase margin of $60^{\circ}$. Figure 17 shows the Bode plots for the designed voltage compensator, for the system without compensation and for the compensated system. The analysis of the diagram allows checking that the specifications imposed for the voltage loop control were also met: bandwidth of $960 \mathrm{~Hz}$ and phase margin of $60^{\circ}$. In order to observe the performance of the controllers, the closed-loop system was simulated. Figure 18 shows

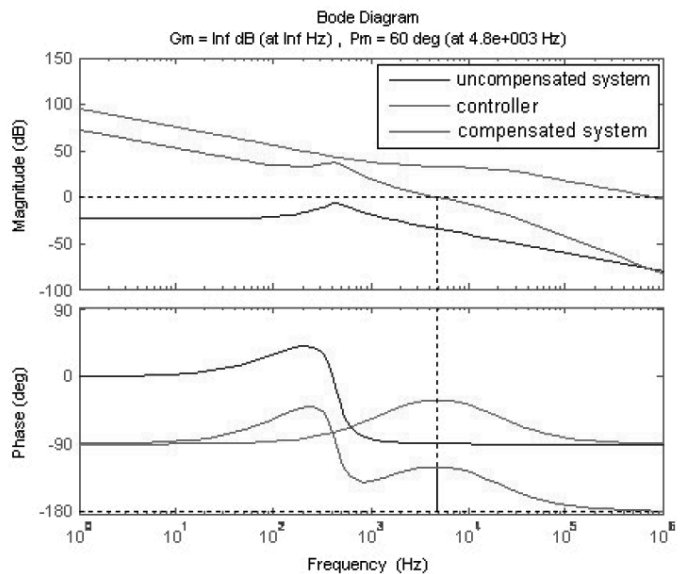

Figure 16. Bode diagram for the current loop.

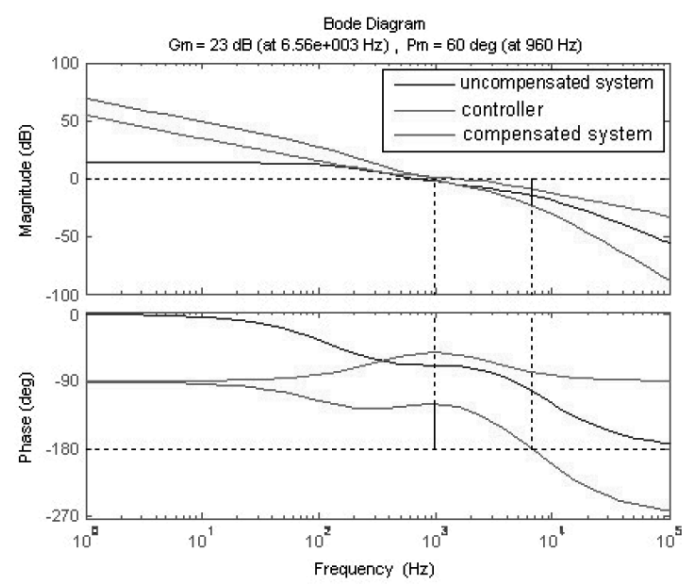

Figure 17. Bode diagram for the voltage loop.
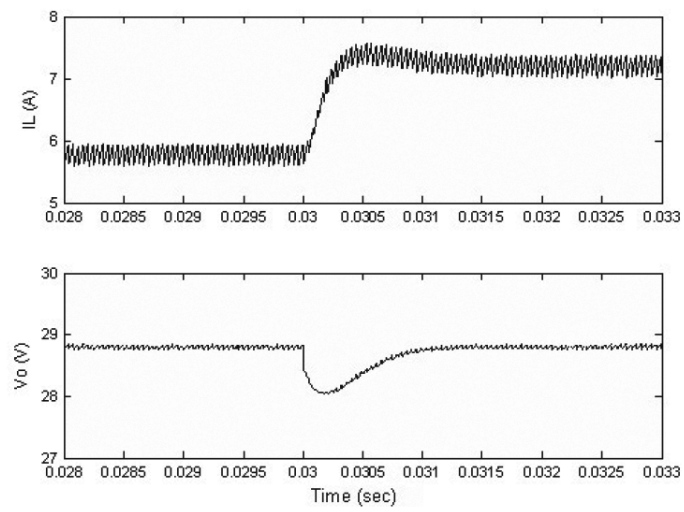

Figure 18. Waveforms for the output voltage and inductor current response to a step input voltage of $20 \%$. 
the dynamical behavior of the load voltage and the inductor current to a variation in the load current of $20 \%$. According to the results obtained, control performance is satisfactory given the quick transient response to disturbances considered.

\section{Discrete time compensators}

The criterion used for selecting the discretization method was based on the best preserved frequency response. Using the discretization tools of Matlab Bode gain and phase curves were obtained for various methods. For the current compensator case, the technique that best preserves the properties of frequency response is the Bilinear Transformation which maintained the properties of gain and phase of the analogical current compensator at least as far as the cutoff frequency $(4800 \mathrm{~Hz})$ as it can be seen in Figure 19. As for the analogical voltage compensator, the Linear Interpolation technique

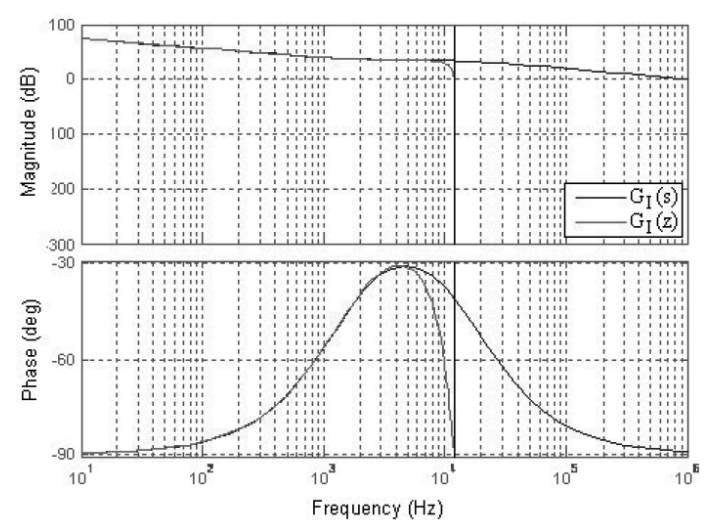

Figure 19. Bode diagrams for the analogical and discrete current compensator.

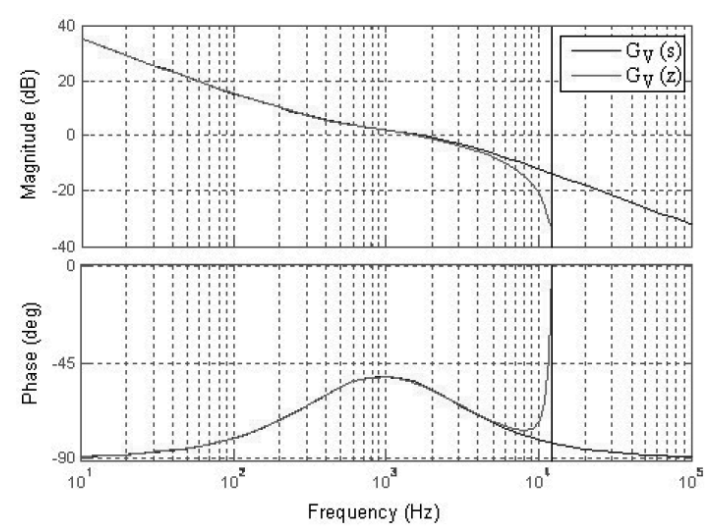

Figure 20. Bode diagrams for the analogical and discrete voltage compensator. has been chosen; the compensator preserved the properties of phase and gain as far as, at least, the cutoff frequency $(960 \mathrm{~Hz})$, as shown in Figure 20. Equation (25) presents the driver discrete current loop transfer function, and (26) the discrete grid voltage controller:

$$
\begin{gathered}
G_{I}(z)=\frac{39.02 \cdot z^{2}+11.55 \cdot z-27.47}{z^{2}-0.611 \cdot z-0.389} \\
G_{V}(z)=\frac{0.2872 \cdot z^{2}-0.003165 \cdot z-0.2227}{z^{2}-1.593 \cdot z+0.5929}
\end{gathered}
$$

Figure 21 shows the response of the output voltage of the average model and its discrete time equivalent subject to an input reference step from $28.8 \mathrm{~V}$ to $27 \mathrm{~V}$. It can be observed an increase in overshoot from $13 \%$ in the continuous model to $20 \%$ of the discretized one. Yet, it can be considered acceptable for the purposes of this study.

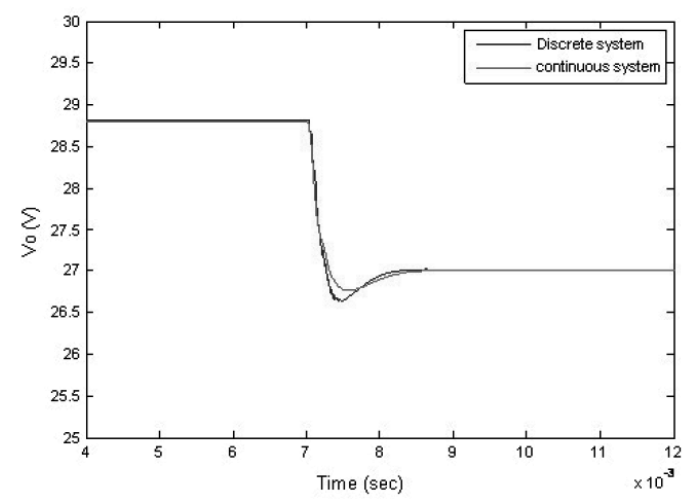

Figure 21. Response to a reference step for the continuous and discrete system.

The detailed modeling of the buck converter by means of the average switching technique, the methodology used for the design of the controllers and the discretization process of the analogical controllers, fall outside the scope of this study and are not presented, however they can be found in detail in [16].

The control system was implemented using a TMS320F2812 digital signal processor from Texas Instruments. Figure 22 shows the flowchart of the strategy developed and Figure 23 shows proposed the control scheme. 


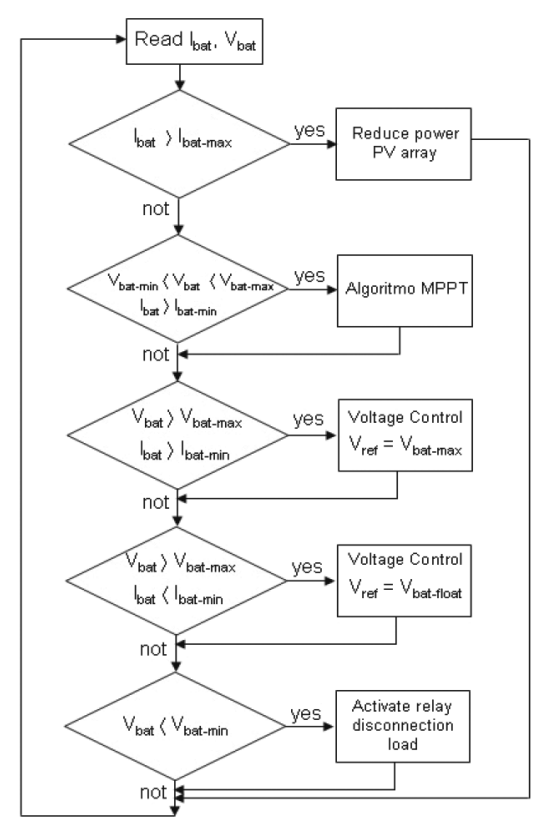

Figure 22. Flowchart of control strategy proposed for the battery charger.

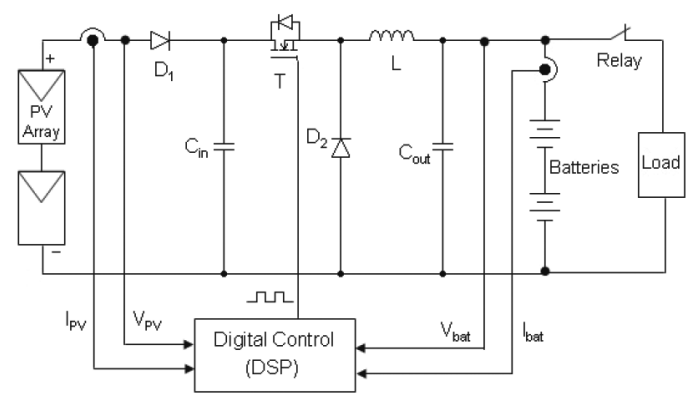

Figure 23. Control scheme proposed for the battery charger.

\section{EXPERIMENTAL RESULTS}

A battery charger was developed using a Buck converter. The prototype is divided into three main circuits, a measuring board, a signal conditioning board and control, and a driving card (Figure 24).

Several tests were made to validate the operation of the charger. Figure 25 shows the test performed in a clear day without clouds throughout the whole test. The batteries were at $15 \%$ of their full charge, approximately, at the beginning of the test. Three relevant variables were measured: the power issued by the panels, the recharging current and the voltage at terminals of the battery stack at intervals of 30 seconds, between 10:00 A. M. and 5:00 P. M.

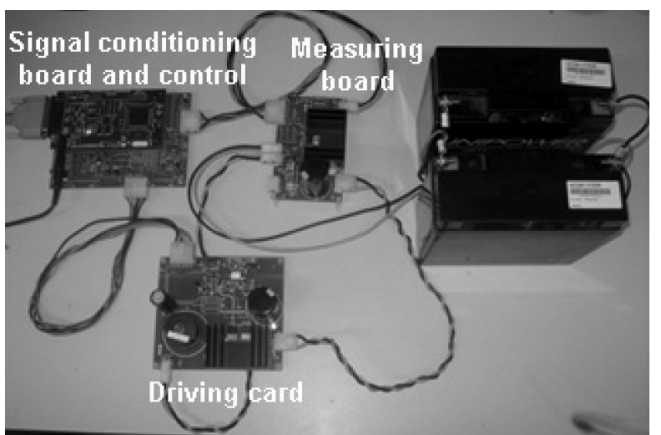

Figure 24. Prototype for the battery charger.
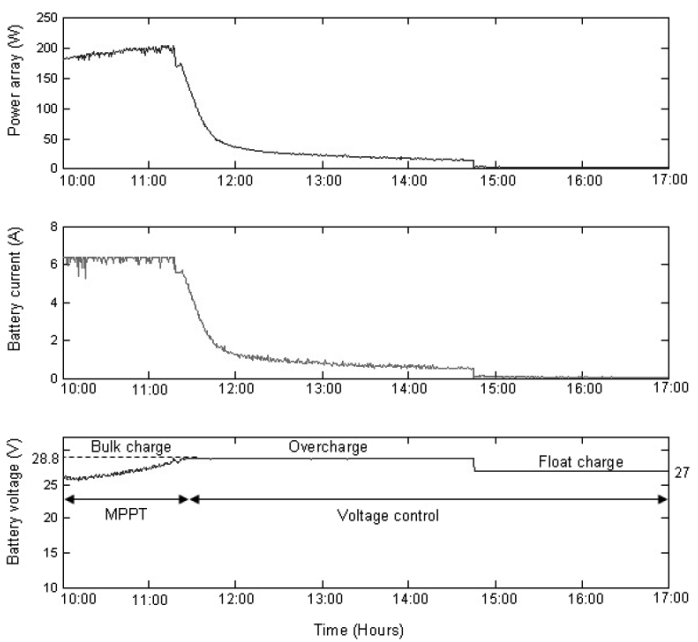

Figure 25. Curves obtained in the test for charging the battery bank.

\section{CONCLUSIONS}

This paper presents a complete methodology for the design and construction of a stand-alone photovoltaic power supply. All stages of development are carefully studied and the most efficient solution is adopted. On the other hand, the method sought to prevent the battery from malfunction in its operation that could compromise its durability. Therefore, a control strategy for the battery charge is also proposed. This control strategy is also in charge of maximizing the production of photovoltaic energy by incorporating an MPPT technique. The proposed methodology can also be replicable to other photovoltaic systems of greater electric energy consumption. Finally, this work is intended to be very practicing engineer orientated with useful guidelines on dimensioning and choosing the most appropriate converter and electronic components. A practical example with 
experimental data for the battery charging process has been given.

\section{ACKNOWLEDGMENTS}

This work was sponsored by Programa de mejoramiento de la calidad de la educación superior (MECESUP-Chile) and Fundação do Amparo à Pesquisa de Minas Gerais (FAPEMIG-Brasil).

\section{REFERENCES}

[1] M.A. Green. "Photovoltaic's: technology overview". Energy Policy. Vol. 28, pp. 989998. November, 2006. ISSN: 0301-4215.

[2] D.P.Hohm and M.E. Ropp. "Comparative study of maximum power point tracking algorithms using an experimental programmable, maximum power point tracking test bed". Photovoltaic Specialists Conference, 2000, pp. 1699-1702. Anchorage, USA. September, 2000. ISBN: 0-7803-5772-8.

[3] S. Liu, R.A. Dougal and E.V. Solodovnik. "Design of autonomous photovoltaic power plant for telecommunication relay station". IEE Proceedings: Generation, Transmission and Distribution. Vol. 152, pp. 745-754. November, 2005. ISSN: 1350-2360.

[4] F.M. Ishengoma and L. Norum. "Design and implementation of a digitally controlled stand-alone photovoltaic power supply". Nordic Workshop on Power and Industrial Electronics. Stockholm, Sweden. August, 2002.

[5] A.P.C. Guimarães, C.M. Ribeiro, L.E.G. Bastos, L.C.G. Valente, P.C.D. Silva and R.X.D. Oliveira. "Manual de Engenharia para Sistemas Fotovoltaicos". Ediouro Gráfica e Editora S.A. Edição Especial, Rio de Janeiro, Brasil. 2004.

[6] Centro de Pesquisas de Energia Elétrica CEPEL. "Centro de Referência para Energia Solar e Eólica Sérgio de Salvo Brito". Date of visit: April 15, 2009. URL: http://www. cresesb.cepel.br./sundata/index.php

[7] International Electrotechnical Commission. "Conformity testing for crystalline silicon terrestrial photovoltaic (PV) modules. IEC 61215". Date of visit: May 10, 2009. URL: http://www.iecee.org/ctl/equipment/pdf/pv/ EL_IEC61215_Ed1_final.pdf
[8] Agência Nacional de Energia Elétrica de Brasil. "Resolução Normativa $\mathrm{N}^{\circ} 83$, de 20 de setembro de 2004". Fecha de visita: April 17, 2009. URL: http://www.aneel.gov. br/cedoc/ren2004083.pdf

[9] B. Cougo, P.C. Cortizo, F.F. Rocha, G.G.B. Coelho, P.F. Seixas and L.V. Machado Neto. "A Photovoltaic System for Remote Fault Detection in Distribution Lines Using a Novel MPPT Algorithm". IEEE International Symposium on, ISIE 2007. pp. 2397-2402. Vigo, Spain. June 2007. ISBN: 978-1-4244-0754-5.

[10] N. Mohan, T. Undeland and W. Robbins. "Power Electronics: Converters, Applications and Design". John Wiley \& Sons. Second edition. New York, USA. 1995. ISBN: 0471142085.

[11] J.A. Gow and C.D. Manning. "Development of a Photovoltaic Array Model for Use in Power Electronics Simulation Studies". IEE Proceedings: Electric Power Applications, Vol. 146, pp. 193-200. March 1999. ISSN: 1350-2352.

[12] R.W. Erickson and D. Maksimovic. "Fundamentals of Power Electronics". Kluwer Academic Publishers. Second edition. Massachusetts, USA. 2001. ISBN: 0-7923-7270-0.

[13] S.J. López, S.I. Seleme Jr., P.F. DonosoGarcia, L.F. Morais, P.C. Cortizo and M.A.S. Mendes. "Comparison of MPPT approaches in autonomous photovoltaic energy supply system using DSP". Industrial Technology (ICIT), 2010 IEEE international conference on. pp. 1149-1154. March, 2010. ISBN: 978-1-4244-5695-6.

[14] Newmax. "Manual Técnico Série 12 volts". Fecha de visita: June 17, 2009. URL: http:// www.newmax.com.br/baterias/br/pages/ downloads.asp

[15] H.D. Venable. "The k-factor: A New Mathematical Tool for Stability Analysis and Synthesis". Proc. of Powercon 10. San Diego, USA. March, 1983.

[16] Julio López S. "Projeto de um sistema fotovoltaico autônomo de suprimento de energia usando técnica MPPT e controle digital". Tesis para optar al grado de Magister. Universidad Federal de Minas Gerais. Belo Horizonte, Brasil. 2009. 